\title{
AN EMPIRICAL INVESTIGATION INTO THE DETERMI- NANTS OF EXTERNAL INDEBTEDNESS
}

\author{
Menbere WORKIE TIRUNEH *
}

\begin{abstract}
:
This paper finds that poverty (the savings gap), income instability, and external factors that include debt service payments and capital flight to be the main causes of overseas borrowing by developing countries in the 1980s and 1990s. As far as the empirical strategy is concerned, the application of a panel data approach seems to be highly preferred, as it allows to control time-specific events that are linked to overseas borrowing, particularly given the rapid changes in the global macroeconomic environment in the past years. Moreover, this strategy helps to produce a more robust explanation by allowing to incorporate country-specific factors as developing countries themselves are heterogeneous in terms of their colonial heritages, geopolitical and strategic significance, and creditworthiness, all affecting the level of indebtedness and the potential bargaining power to manage the subsequent debt crisis.
\end{abstract}

Keywords: external debt, panel data, heavily indebted poor countries

JEL Classification: C13, C33

\section{Introduction}

The causes of the external indebtedness of developing countries and their subsequent failure to meet contractual international debt obligations have generated heated debates both in the academic circles, policy makers, and in the broader international community since the outset of the debt crisis in 1982. While poverty and external factors seem to be the most profound factors behind the external indebtedness of poor nations, there is still an ongoing debate on the determinants of the demand for overseas borrowing by developing countries. In this regard, the problem of developing countries' external debt is believed to be one of the major challenges of the new millennium. The debate has been further intensified thanks to the involvement of not only the traditional international financial institutions, but also inde-

*) University of Munich, Empirical Research Group, Ludwigstrasse 28/RG, 80539 - Munich, Germany and Institute of Slovak and World Economy, Slovak Academy of Sciences, Šancova 56, 81105 - Bratislava, Slovakia (e-mail: menberew2000@yahoo.com).

${ }^{* *}$ ) I would like to thank Stephan Klasen and participants of the Munich seminar in empirical economics for their valuable comments. 
pendent analysts, and non-governmental organizations (NGOs), which ultimately put the international community, particularly the developed world, under serious pressure to write off the external debt of the poorest countries of the world.

Although it is generally believed that external debt helps countries that are suffering from capital deficiency to achieve accelerated economic growth, once this financial gap becomes unmanageable, the past-accumulated external debt is likely to provoke further external borrowing, creating a vicious circle problem. This obviously creates a gloomy picture on future growth prospects and reduces the likelihood of developing countries to meet their debt - service obligations, which is exactly the current experience of the poorest nations of the world, earning the new name "heavily indebted poor countries" (HIPCs).

The debate is particularly crucial given the factors behind this huge debt created so far. Although poverty (the savings gap) seems to be the natural reason behind overseas borrowing, there are additional, mainly exogenous, factors that drove most developing nations into chronic external debt crisis (see also Workie Tiruneh, 2002). The most frequently cited determinants of overseas borrowing in the 1970 s and 1980s are the two-oil price shocks of the early and late 1970s, the subsequent recession in major industrialized countries, the change in the global economic policy and the deterioration in developing countries terms of trade are just some of them - to mention a few. On the supply side, the generous and irresponsible lending policies of private commercial banks in industrialized countries, which is linked to the recycling of the "petrodollars" is another widely acknowledged root cause behind developing countries debt accumulation. Even worse is, in this context, that as private commercial banks were fast to discharge loans to developing countries in the 1970s, they were even faster to cut lending when the first sign of the debt crisis came into play following Mexico's official announcement in August 1982 when it was no longer able and willing to meet its contractual international debt obligation. ${ }^{1)}$

It should, however, be added that irresponsible and corrupt governments (sometimes unelected ones) in developing countries themselves are the key players of the debt build-up. Such governments across the developing world, like Mobutu of Zaire, have been accused of shamelessly squandering their nations' scarce resources for luxurious activities rather than investing them to improve the lives of these desperately poor nations. The joint effects of all these and other factors led most indebted countries to experience multiple debt crisis, which ultimately forced them to undertake frequent rescheduling and beg for debt reduction and relief.

The objective of this paper is to add to the current empirical literature on the determinants of overseas borrowing by developing countries in the 1980s and 1990s. To answer this question, the remainder of the paper is divided into six parts. Part two presents the general theoretical discussion on the evolution of the debt crisis with emphasis on HIPCs. Part three presents the theoretical model on debt determinants. Part four, briefly discusses some past empirical studies. Part five discusses the specification of the empirical model and the variables under investigation. Finally, part six summarizes the highlights of this study and its policy implications.

1) The abnormal nature of the external debt problem of developing countries in the 1970s and $1980 \mathrm{~s}$ was best expressed by the popular joke of the 1930s, which characterizes private credit as "an umbrella that a person is allowed to borrow as long as the weather is fine, but which he has to return in the moment it starts raining" (in Nafziger, 1993, p. 151). 


\section{Why Indebted Countries Got Indebted in the First Place?}

External borrowing is not a new phenomenon at all. Most of today's industrialized countries had been net borrowers in their path to economic development. This part mainly discusses the reasons behind developing countries indebtedness in the 1980 s and 1990s. The arguments for overseas borrowing and lending are numerous. Though it is well known, there is a lender to every borrower, I will rather focus my analysis on the indebted countries, hence the demand side of external indebtedness. The supply side will only be marginally discussed when relevant. The causes of external indebtedness might be classified into four categories: poverty-driven indebtedness (the savings gap), the foreign exchange gap, the return argument, and the contribution of external factors.

\section{1 The Saving Constraint as Driving Force Behind External Indebted- ness}

There is a widespread consensus among growth economists that poverty plays an enormous role in driving countries into serious external indebtedness. In this context, from the view point of debtors, the economic justification to borrow overseas is associated with the rising gap between national savings and domestic investment. ${ }^{2)}$ That is, as many argue, at the expense of running a current account imbalance, a country may manage to obtain resources to invest even if its domestic saving level is low. Several studies associate the major cause of external indebtedness to the poverty-vicious circle type of argument. For example, Singer (1990, in Nigel, 1995), argues that the external imbalance is caused by the vicious circle of poverty: poor people are poor because they are undernourished or illiterate, and they are undernourished and illiterate because they are poor. In the same token, poor countries are poor because they have low savings and investment and they have low savings and investment because they are poor.

Similarly, Root (1990), among others, argue that the major development obstacle of developing countries is the vicious circles of the saving - investment gap described as follows: productivity is low because investment is low, investment is low because savings are low, saving are low because income is low, income is low because productivity is low; thus, in a very real sense, according to Root the poor nations are poor because they are poor. The savings gap, therefore, reflects the inability of poor countries to save sufficient amount of resources to finance the desired level of investment necessary for self-sustained growth. Overseas borrowing is bound to fill this gap by generating resources that domestic savers are unable or unwilling to sacrifice. ${ }^{3)}$ From this standpoint, it is possible to argue that the deficit in poor countries is simply a development deficit that is inevitable if countries were to achieve long-run positive economic growth. Such a deficit, however, is not without cost as it increases foreign debt, which must be serviced and repaid in the future. Ferraro and Rosser (1994) also take this same line, where they strongly link the

2) For the formal treatment of the savings gap and the foreign exchange gap (the two-gap model) see Basu (2000).

3) Many believe that under the circumstances of low level of savings, overseas borrowing by the public sector may help the private investment via the public investment and avoids possible crowding out effect of the private investment through domestic borrowing. This may also feed the economy with additional foreign exchange to finance past accumulated debt and imports (see Serieux, 2001). 
external indebtedness of developing countries to their level of poverty. ${ }^{4)}$ Table 1 indicates that HIPCs are substantially lagging behind non-HIPCs counterparts in income per capita level, gross domestic savings and investment, literacy rates and life expectancy. In contrast, they send out more resources abroad in the form of debt service payments.

Table 1

Some Economic and Social Indicators for HIPCs and Non-HIPCs

\begin{tabular}{|l|c|c|c|c|}
\hline \multirow{2}{*}{ Economic and social indicators } & \multicolumn{2}{|c|}{$\begin{array}{c}\text { Heavily indebted poor } \\
\text { countries (HIPC) }\end{array}$} & \multicolumn{2}{c|}{ Low \& middle income } \\
\cline { 2 - 5 } & $1980-1989$ & $1990-1998$ & $1980-1989$ & $1990-1998$ \\
\hline GDP per capita (constant 1995 USD) ${ }^{1)}$ & 310.69 & 338.10 & $1,158.65$ & $1,341.01$ \\
\hline Gross domestic investment (\% of GDP) & 17.82 & 19.25 & 27.82 & 29.28 \\
\hline Gross domestic savings (\% of GDP) & 11.01 & 12.16 & 27.99 & 28.70 \\
\hline Total debt service (\% of exports) & 24.41 & 20.61 & 22.52 & 18.90 \\
\hline Illiteracy rate, adult total ${ }^{2)}$ & 53 & 44 & 38 & 31 \\
\hline${\text { Life expectancy at birth, total (years) }{ }^{3)}}^{3}$ & 50 & 52 & 60 & 63 \\
\hline
\end{tabular}

1) The $1980-1989$ average is only $1984-1989$.

2) This is data for 1980 and 1990.

3) This is data for 1980 and 1990.

4) HIPCs are countries with total external debt to exports ratio of greater than $150 \%$ (net present value terms) and GDP per capita of less than USD 800. ROM).

Source: Own calculations based on data from the World Bank, World Development Indicator, 2001 (CD-

The poverty driven indebtedness is particularly alarming to heavily indebted poor countries. As Serieux (2001, p. 307) rightly puts it, "heavily indebted" and "poor" clearly "spells out the combined attributes that HIPCs apart from other developing countries and make them a focus of concern for northern governments, international public agencies, and international civil-society organizations". All the gap models argue in this direction. ${ }^{5}$ Classens, et al. (1996) also indicates that HIPCs situation differ from other middle-income debtors in several respects that include the

4) Their analysis is based on the 1990 UN Chronicle that presents the following statistical evidence on poverty across the world. Ferarro and Rosser, 1994: 1 billion people live in absolute poverty, 100 million persons are completely homeless, 800 million are hungry everyday, 1.75 billion people are without access to safe drinking water, and 1.5 billion are without access to primary education, an alarming figure that demonstrates the severity of poverty across developing countries, many of which are members of HIPCs.

5) For a further discussion, see Agenor and Montiel (1996), Taylor (1994), and Bacha (1990), among others. In this context many argue that overseas borrowing may be beneficial to generate higher economic growth if an increase in investment contributes to higher growth, which generates additional foreign exchange to finance past accumulated debt. In this context Healey (1995, in Nigel, 1995) among others, argue that foreign capital would be translated into growth if the savings and foreign-exchange gaps can in due course be reversed, and the funds are invested in projects that generate higher rate of returns compared to the cost of borrowing, hence the market interest rate. Similarly, others, for example, Easterly (1999) argue that if aid is viewed as a permanent income by a developing country government, the recipient government is highly likely to spend these resources on boosting consumption rather than investment, making aid meaningless in terms of boosting growth. The endogenous growth theory is also in this line. The central argument is that if aid is transferred as a lump sum, it would have no impact on investment. 
poor income level and poor economic reform in this group. The IMF in its recent study acknowledges, that 'the increase in many low-income countries' debts, beginning in the 1970s and peaking in the 1980s, was accompanied by disappointing performance in their struggle against poverty" $\left(2003\right.$, p. 6). $\left.{ }^{6}\right)$

\section{2 The Foreign-exchange Constraint}

Another equally important justification behind the overseas borrowing of developing countries is that of the foreign exchange gap. Because even assuming that there were no capital deficiency and no savings gap, the growth rate of developing countries may still be hindered by foreign exchange gap. This seems to suggest that domestic savings is a necessary but not a sufficient condition for raising investment in developing countries to a desired level. ${ }^{7)}$ This is again linked to the import structure of developing countries where imports of capital goods are vital for the further expansion of the tradable sector. The significance is twofold given the very truth that most of least income countries own domestic currencies that are not freely convertible. Moreover, export earnings are usually insufficient to generate enough foreign exchange to finance imports making overseas borrowing the indispensable means of gaining access to the technology that is vital for the expansion of the export sector that ultimately leads to rapid economic growth.

\section{3 The Return Argument for Overseas Borrowing}

Though it is more of a supply-side story, the return argument is another justification for overseas borrowing. ${ }^{8)}$ The central argument here is that since poor countries are suffering from financial deficiency and in contrast, there is a surplus in developed countries, capital should move from the latter to the former. The neo-classical growth theory argues that as the ratio of capital to labour in developing countries (LDCs) is lower, the marginal product of capital is bound to be higher. In contrast, in countries with high capital to labour ratio (because of high level of savings) and the investment opportunities exploited already, savings of these countries are invested in developing countries where they turn out to generate higher expected rates of returns. This seems to suggest that the flow of resources from rich to poor countries is mutually beneficial. The LDCs can make use of the excess savings of the rich countries for financing their investment while the lending developed countries would potentially generate high rates of returns by investing in poor countries as opposed to in their own countries. Therefore, as Nigel (1995), among others, argue theoretically economic efficiency (the marginal efficiency of capital) and commercial logic dictate that capital should flow from the relatively less-profitable "First World" to the relatively more-profitable "Third World". 


\section{4 External Factors as Driving Force for External Indebtedness}

The evolution of the debt crisis goes back to the two oil-price shocks of the $1973-1974$ and $1979-1980$ and the subsequent recession of the world economy. Most of today's indebted poor countries got indebted mainly during and after these periods. This has been accompanied by the dramatic fall in the terms of trade of mainly primary commodities, which further widened the financial gap and made things even more complicated.9) An increase in the price of oil increased its revenue in excess of these countries' demand. These "petrodollars" were, therefore, deposited in eurodollar markets by OPEC countries. The "fund-starved" developing countries borrowed these funds from the eurodollar market to pay their import bills from Europe, the United States and Japan (see Schema). Moreover, most developing countries themselves are net importers of oil adding a further pressure on their demand for foreign exchange either in the eurodollar market or else where.

The Recycling of the Petrodollar Scheme

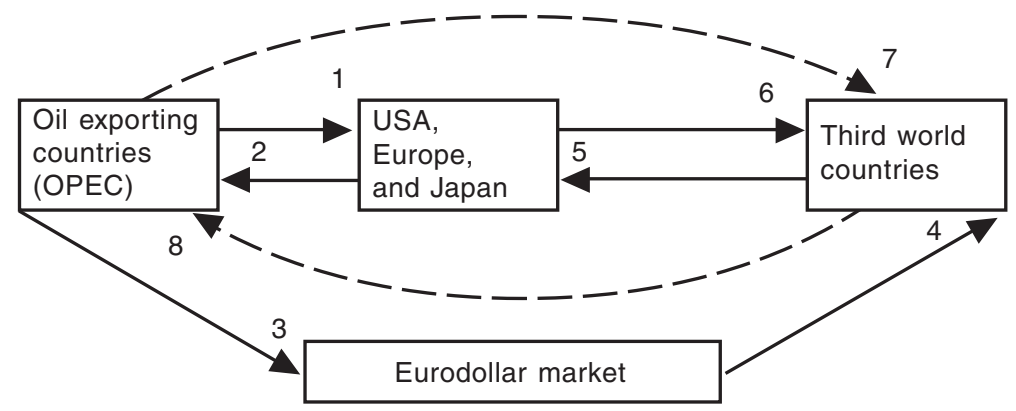

1. oil transfer; 2. monetary transfer; 3. monetary transfer; 4. monetary transfer; 5. monetary transfer; 6. transfer of goods; 7 . oil transfer; 8 . monetary transfer.

Source: Chacholiades, 1990, p. 395 (numbers 7 and 8 added).

While Schema indicates the evolution of the debt build-up in developing countries in the 1980s, the debate on how poor nations got indebted is far from over. One of the major debates on the exogenous causes of the debt crisis in the 1980s is linked to the change in the global macroeconomic policy from the part of developed countries that developing nations could not help at all. Such policy changes include but are not limited to the dismantling of the Bretton-Wood monetary system, and the switch from an expansionary monetary policy to a restrictive monetary policy.

9) Although initially the OPEC had functioned properly, things moved to a different direction in 1973 because of the Arab-Israeli war when the Arab members of the OPEC temporarily embargoed oil exports to the United States and other pro-Israeli countries. As soon as the Arab oil embargo was lifted in 1974, the OPEC made use of the temporary supply shortage to increase the price of crude oil within three months (from USD 2.59 to USD 11.65 a barrel (see Pilbeam, 1992; Chacholiades, 1990; Nafziger, 1993; among others). The Iranian revolution was another phenomenon for the rise of oil price in 1978, where Iran that had produced nearly 20 per cent of OPEC exports suddenly disappeared from the world oil market. This already bad situation got even worse when the war broke out between Iran and Iraq resulting in the rise of Saudi Arabian light crude oil price, which reached the record level of USD 32 a barrel (see Chacholiades, 1990, among others). 
What is even worse is that these policy changes took place during the second oil shock of 1979 - 1980, together with persistently high inflationary expectations and large deficits in the United Sates, boosted real interest rates up to almost $10 \%$ (see Nafziger, 1993), among others. The spill-over effects of these and other policy changes had been particularly detrimental to the growth prospects of poor nations. Higher real interest rates, for instance, meant high debt service payments and as the result, little resources were left over for domestic investment, which hampered subsequent economic growth, which again leaded to higher demand for external loans.

Others, for instance, Dymski (2002), accuse of multinational banks in developed countries in the late 1970s and early 1980s for "pushing" credit on to less-developed countries because of their competition to get rid-of the accumulated petrodollars. Some call this as "the herd instinct about investors", where lenders found themselves in an aggressive competition to lend to developing countries. ${ }^{10)}$

Schwartz (1988, p. 9-10) argues in this line, that "the current debt problem differs from historical ones in at least two respects: first, in the present case, international debt settlement involves not only the private creditors and debtor countries but also international agencies and creditor-country governments. Second, in the present case, the creditors have been urged, if not coerced, lending and however reluctantly, have continued lending to troubled nations." As she argues, this was not the case in the past when the creditors were bondholders. As Schwartz further argues, the hidden thought behind lending new money was to protect the old money lent. Similarly, Ferarro and Rosser (1994) link the debt crisis of the 1980s to the irresponsible lending policies of the industrialized countries. As they put it, "the proof of the wrong-mindedness of lending in the 1970s, became dramatically apparent in 1981" (p. 6). Like all other debt theorists, they further blame the rise in the interest rates, and the deterioration in the terms of trade of primary commodities. ${ }^{11)}$

But the conclusion is rather mixed. While Sachs and Berg (1988) believe that in many of the indebted countries external debt in the 1970s was provoked by irrational political decision (borrowing overseas rather than raising the tax rates to avoid domestic political risk), they also acknowledge that this indebtedness was aggravated by other structural changes, such as expansionary US-monetary policy in the early 1970s, the breakdown of the fixed exchange rate system and the subsequent sharp rise in global liquidity, OPEC oil price shock and the subsequent growth of "petrodollar recycling", and the dimming of bankers' memories of defaults on sovereign loans in the Great Depression.

Similarly, Easterly (2002) associates the current debt crisis to the wrong investment policies of the indebted nations, among other things. As he puts it, "the HIPCs debt problem arose not because of new borrowing, but because of disinvestment in productive potential" (p.1683). Moreover, the uniqueness of HIPCs indebtedness mirrors the absence of any substantial improvement in the economic growth of this group despite decades of structural adjustment and external aid. In contrast, the debt build-up continued to mount.

10) In a similar fashion, Vos (1994, in Dymaki, 2002), argues that the main driving force of overlending was the oligopolistic nature of overseas lending markets, competitors goal of expanding their market share, and lenders tendency to underassess risk. He added that most current LDC borrowers have defaulted in the past, more than once.

11) Ferarro and Rosser (1994) indicate that the very deep recession of 1981 - 1982 made it impossible for developing countries to pay back their loans. They also argue, quoting UNCTAD, commodity prices (for essentially food stuff, fuels, minerals) dropped by $28 \%$ in 1981 - 1982, and interest payments on loans increased by $50 \%$ in nominal terms and $75 \%$ in real terms" (p. 6). This is also consistent with Wayne (1993) and the Jubilee (2000) initiative. 


\section{Determinants of Demand for Overseas Borrowing: a Theoretical Model}

Here I first summarize the theoretical framework that justifies the need for external overseas borrowing by developing countries. ${ }^{12)}$ The framework is adapted from McFadden, et al. (1983). The model begins by summarizing the determinants of the current account (CA) balance, where CA is the difference between items that generate foreign exchange and those that require foreign-exchange expenditure.

$$
C A=X-M-I L F-O T P
$$

where $X=$ export; $M=$ imports; $I L F=$ interest paid on loans from foreigners and OTP $=$ other net factors payments and transfers to foreigners.

$$
C A=\Delta N I R+\Delta B F-\Delta L F-F D I
$$

Equation (2) is another way of writing the current account surplus of equation (1). This time, the current account is the difference between changes in the international reserves $(\triangle N I R)$ and foreign bonds placed domestically $(\triangle B F))$, and an increase in loans from foreigners $(\triangle L F)$ and foreign direct investment $(F D I)$. Then, the change in loans from foreigners $(\Delta L F)$ is basically the difference between new foreign loans $(N)$ and payments of foreign loan principal $(P L F)$. Then, demand for new foreign loans $(N)$ would be:

$$
N=P L F+I L F+\Delta N I R+\Delta B F-F D I+O T P-X+M
$$

Equation (3) implies that the demand for new foreign loans is an increasing function of payments of foreign loan principal due; interest paid on loans from foreigners; $\triangle N I R ; \triangle B F$; OTP; and imports; and a decreasing function of exports $(X)$ and foreign direct investment $(F D I)$.

Now, the sum of interest (ILF) and principal ( $P L F)$ payments paid is nothing other than total debt service paid $(D S P)$. The $D S P$ is also nothing else other than the difference between total debt service due $(D S D)$, which incorporates also past arrears outstanding and current arrears $(A)$. Substituting these relationships into equation (3), they found equation (4), which represents the demand for new foreign loans.

$$
N+A=D S D+\Delta N I R+\Delta B F-F D I+O T P-X+M
$$

The assumption they follow here is that countries prefer to protect their reputation by rolling over their external debt rather than by arrears. This gives an equation for a one-period - ahead ex ante demand for new loans, which satisfies:

$$
N^{D}=D S D^{e}+\Delta N I R^{e}+\Delta B F^{e}-F D^{e}+O T P^{e}-X^{e}+M^{e}
$$

where $N^{D}$ stands for new loan demanded, and the superscripts e stands for expectations and other variables are as defined above.

From equation (5) it implies that the demand for overseas borrowing is an increasing function of total debt service, the change in international reserves, the change in foreign bonds placed domestically (which partly reflects capital flight), net transfers to foreigners, and imports of goods and services. In contrast, capital inflows in the form of foreign direct investment and export revenues reduce the demand for external borrowing.

12) Dornbusch (1984, in McFadden, et al. 1985) links the increase in gross external debt to (current account deficit - direct and long-term portfolio capital inflows) + (official reserve increases + other private capital outflows). 


\section{A Summary of Previous Empirical Studies}

Several empirical studies investigated the determinants of external borrowing. Although they all have the same fundamental arguments, they deviate with respect to the choice of covariates that determine the demand for external loans and their methodological approaches. Eaton, et al. (1981) was among the first to look at this issue. The theoretical model and its corresponding empirical counterpart are based on the following assumptions: first, the amount of a country's debt is determined by its willingness to borrow and a credit ceiling. Second, a rise in income variability (measured by the standard deviation of exports) boosts the demand for borrowing. Third, while a rise in the growth rate of GDP leads to higher demand for borrowing, it decreases or increases the credit ceiling depending of the degree of risk aversion. ${ }^{13)}$ Finally, if the utility function exhibits constant relative risk aversion, then the income elasticities of both the ceiling and willingness to borrow are one. They also empirically show, using logit model and data for 81 countries for the periods 1970 and 1974, that the demand for borrowing is positively related with income variability, ratio of import to GDP, and initial income.

Eichengreen and Portes (1986), using both annual cross-section from $1930-$ 1938 for 16 to 23 countries and panel data indicate that while export instability and degree of openness are positively correlated with government external debt, they are not statistically significant. The only explanatory variable that was always significantly different from zero is the log of GDP per capita (LGDP). Shifting their approach to panel data, they indicate that all the variables but export variability turned out to be statistically significant. Though they recognized the problem of potential simultaneity, they have done little to resolve this problem.

On the other hand, in a different approach, Hajivassiliou (1987), using data for 79 developing countries in the period $1970-1982$, and treating the demand for and the supply of loans separately, finds out that the demand for borrowing is positively determined by total debt service to export ratio, growth of GDP per capita, import to GDP ratio, interest and principal to export ratios and negatively by real GDP per capita (in contrast to both Eichengreen's and Eaton's, who used GDP). Similar results were obtained by McFadden, et al. (1983).

The latest study on the determinants of indebtedness is that of Easterly, whose empirical strategy was to regress an average of each policy indicator or macroeconomic imbalance (over the debt relief period, 1980 - 1997) on the log of initial income, and a dummy for HIPCs for the whole sample of less-developed countries. The objective was to identify the determinants of HIPCs indebtedness. For this analysis, he relies on the following hypotheses: First, HIPCs become HIPCs through unfavourable exogenous shocks, such as terms of trade and war. Second, highly indebted countries tend to exercise bad policies. Third, heavily indebted countries have a greater desire to discount the future. Finally, "the irresponsible lender story predicts that public debt will substitute private debt" (p. 1682). His main conclusion is that HIPCs got indebted due to bad policies, on the one hand, and with the help of international financial institutions, on the other hand.

13) Following Eaton, et al. (1981), "a negative effect of growth on the ceiling is more likely the more risk averse is the country, the more rapidly its risk aversion falls with increase in income, and possibly, if the per cent variability of income falls as income increases" (p. 301). 


\section{The Empirical Model, Data Description and Re- sults}

Recognizing that previous empirical studies have produced fruitful results, there seems to be a room for extending those studies by considering the following:

- the 1980s and partly 1990s witness that capital flight has been a disastrous phenomena for developing countries. I, therefore, include this variable in this regression;

- the role of the fall in the terms of trade that has been ignored by previous studies should be given an appropriate attention;

- one needs to separately deal with whether the demand for external borrowing for HIPCs differ from those of other LDCs. This has been taken care of by two approaches. One approach is simply by putting a dummy for HIPCs in the regression for all samples and the second one is by running a separate regression for HIPCs alone. Since the number of HIPCs with full data is around 21, sometimes even less, I run a cross-section pooled time-series rather than a fixed effects model. Otherwise, there would just be not enough degrees of freedom;

- thirdly, for all observations, I run random and fixed effects model to control for country and time-specific effects; ${ }^{14)}$

- finally, to my knowledge, except Easterly's 2002, there is no fresh empirical work in this area to explore the demand for indebtedness in the 1980s and 1990s.

$$
\begin{aligned}
& \text { LEDTGDP }=\alpha+S D X+M G D P+C F L X+T D S X+L T O T+ \\
& (+) \quad(+) \quad(+) \quad(+) \quad(-) \\
& +\angle G D P+G R G D P+L P O P \\
& (+) \quad(-) \quad(+)
\end{aligned}
$$

The basic empirical model that captures the covariates and their expected signs is just above. The dependent variable is the logarithm of total external debt as a ratio to GDP. The variables, their definitions and sources are presented in Table 2. Table 3 presents the list of countries that are studied in this paper. Table 4 presents fixed effects and random effects model results for LEDTGDP. ${ }^{15}$ ) Table 5 presents differences in the mean values of the covariates for HIPCs and non-HIPCs, while Table 6 presents the impact of each covariate on the difference in the level of log of total external debt to GDP ratio (LEDTGDP). Table 7 presents cross-section pooled time series results for HIPCs.

14) The panel data approach is particularly important when analyzing the causes of indebtedness. As Hajivassiliou (1987) correctly puts it, except the traditional advantage of the panel data approach, developing countries seem to differ from each other due to colonial histories, political and financial institutions, and degree of creditworthiness. Therefore, the problem of heterogeneity might be substantially reduced by allowing country-specific factors. Moreover, the time-specific dummy may help to control for swings in international economic policies and indebtedness and debt relief over time.

15) The regression results for the level of total external debt as a dependent variable have not been reported for space consumption reasons. 
Table 2

Definitions of Variables Used in the Regression $(1982-1998)^{1)}$

\begin{tabular}{|l|l|l|}
\hline Variable & Definition & Source \\
\hline LEDTGDP & $\begin{array}{l}\text { logarithms of total external debt to } \\
\text { GDP ratio (average 1982 - 1998) }\end{array}$ & $\begin{array}{l}\text { Global Development Finance, } \\
\text { CD-ROM, 2000 }\end{array}$ \\
\hline SDX & $\begin{array}{l}\text { Standard deviation of exports } \\
\text { (1995 constant prices) }\end{array}$ & World Development Indicators, 2001 \\
\hline TDSX & Total debt service due to exports ratio & $\begin{array}{l}\text { Global Development Finance, } \\
\text { CD-ROM, 2000 }\end{array}$ \\
\hline CFLX & $\begin{array}{l}\text { Capital flight to export ratio. The } \\
\text { "sources and uses" methodology: } \\
\text { capital flight }=(\text { change in debt }+ \\
+ \text { foreign direct investment) }-(\text { current } \\
\text { account deficit }+ \text { change in reserves) }\end{array}$ & $\begin{array}{l}\text { Global Development Finance, CD-ROM, } \\
\text { Indicators, 2001 }\end{array}$ \\
\hline LTOTG & $\begin{array}{l}\text { The logarithms of the percentage } \\
\text { change in the terms of trade }\end{array}$ & Easterly and Mirvat, 2002 \\
\hline MGDP & Imports to GDP ratio & World Development Indicators, 2001 \\
\hline LGDP & Log of GDP (PPP-adjusted) & World Bank, Easterly and Mirvat, 2002 \\
\hline GRGDP & Growth rate of GDP (PPP-adjusted) & World Bank, Easterly and Mirvat, 2002 \\
\hline LPOP & Log of population & World Development Indicators, 2001 \\
\hline
\end{tabular}

1) All covariates are initial values to minimize possible endogeneity problem.

Table 3

List of Countries Included in the Regression ${ }^{1)}$

\begin{tabular}{|l|ll|}
\hline Heavily indebted poor countries & Non-heavily indebted less-developed countries \\
\hline Bolivia & Argentina & Mauritius \\
Burkina Faso & Bangladesh & Mexico \\
Cameroon & Belize & Morocco \\
Chad & Botswana & Nigeria \\
Congo, Rep. & Brazil & Pakistan \\
Cote d'Ivoire & Chile & Panama \\
Ethiopia & Colombia & Papua New Guinea \\
Ghana & Costa Rica & Paraguay \\
Honduras & Dominican Republic & Peru \\
Kenya & El Salvador & Philippines \\
Madagascar & Gabon & Swaziland \\
Malawi & Gambia & Thailand \\
Mauritania & Guatemala & Togo \\
Mozambique & Haiti & Tunisia \\
Nicaragua & India & Uganda \\
Niger & Indonesia & Venezuela, RB \\
Rwanda & Iran, Islamic Rep. & Zambia \\
Senegal & Jordan & Zimbabwe \\
Sierra Leone & Korea, Rep. & \\
Trinidad and Tobago & Lesotho & \\
Uruguay & Malaysia & \\
\hline
\end{tabular}

1) The number of countries included in the observation resulted from the data availability. 
Table 4

Panel Regression Results for All Developing Countries (1982 - 1998) ${ }^{1}$

\begin{tabular}{|c|c|c|c|c|c|c|c|c|}
\hline & \multicolumn{4}{|c|}{ Random effects model } & \multicolumn{4}{|c|}{ Fixed effects model } \\
\hline Variable & 1 & 2 & 3 & 4 & 5 & 6 & 7 & 8 \\
\hline Const & $\begin{array}{c}6.222^{* * * 3)} \\
(4.15)^{4)}\end{array}$ & $\begin{array}{c}6.753^{\star * *} \\
(4.79)\end{array}$ & $\begin{array}{c}7.121^{* * *} \\
(5.39)\end{array}$ & $\begin{array}{c}6.848^{* * *} \\
(5.26)\end{array}$ & $\begin{array}{l}-5.366 \\
(-0.43)\end{array}$ & $\begin{array}{c}-13.721 \\
(-1.23)\end{array}$ & $\begin{array}{l}-9.112 \\
(-0.83)\end{array}$ & $\begin{array}{c}-10.145 \\
(-0.90)\end{array}$ \\
\hline SDX & $\begin{array}{c}0.00005^{*} \\
(1.79)\end{array}$ & $\begin{array}{c}0.00005^{\star *} \\
(2.09)\end{array}$ & $\begin{array}{c}0.00005^{*} \\
(1.93)\end{array}$ & $\begin{array}{c}0.00004^{*} \\
(1.68)\end{array}$ & $\begin{array}{c}0.0001^{* *} \\
(2.85)\end{array}$ & $\begin{array}{c}0.0001^{* * *} \\
(2.95)\end{array}$ & $\begin{array}{c}0.0001^{* * *} \\
(2.87)\end{array}$ & $\begin{array}{c}0.0001^{* * *} \\
(2.78)\end{array}$ \\
\hline CFLX & & $\begin{array}{c}0.0014^{* * *} \\
(3.47)\end{array}$ & $\begin{array}{c}0.0015^{\star * *} \\
(3.59)\end{array}$ & $\begin{array}{c}0.0014^{* * *} \\
(3.58)\end{array}$ & & $\begin{array}{l}0.001^{* *} \\
(2.26)\end{array}$ & $\begin{array}{l}0.001^{* *} \\
(2.29)\end{array}$ & $\begin{array}{l}0.001^{* *} \\
(2.29)\end{array}$ \\
\hline TDSX & & & $\begin{array}{c}0.0095^{\star * *} \\
(4.16)\end{array}$ & $\begin{array}{c}0.0098^{* * *} \\
(4.32)\end{array}$ & & & $\begin{array}{c}0.0062^{* *} \\
(2.68)\end{array}$ & $\begin{array}{c}0.006^{* * *} \\
(2.69)\end{array}$ \\
\hline LTOTG & & & & $\begin{array}{l}-0.004^{* *} \\
(-2.19)\end{array}$ & & & & $\begin{array}{c}-0.0064 \\
(-1.35)\end{array}$ \\
\hline MGDP & $\begin{array}{c}0.0056^{* *} \\
(2.02)\end{array}$ & $\begin{array}{l}0.0025 \\
(0.98)\end{array}$ & $\begin{array}{l}0.0037 \\
(1.51)\end{array}$ & $\begin{array}{c}0.0039^{\circ} \\
(1.61)\end{array}$ & $\begin{array}{c}0.0071^{* *} \\
(2.14)\end{array}$ & $\begin{array}{c}0.0032 \\
(1.04)\end{array}$ & $\begin{array}{l}0.0039 \\
(1.30)\end{array}$ & $\begin{array}{c}0.0038 \\
(1.25)\end{array}$ \\
\hline LGDP & $\begin{array}{l}-0.218^{* *} \\
(-1.99)\end{array}$ & $\begin{array}{l}-0.213^{\star * *} \\
(-2.05)\end{array}$ & $\begin{array}{l}-0.236^{* *} \\
(-2.44)\end{array}$ & $\begin{array}{l}-0.214^{*} \\
(-2.25)\end{array}$ & $\begin{array}{l}-0.661^{*} \\
(-3.18)\end{array}$ & $\begin{array}{l}-0.454^{*} \\
(-2.39)\end{array}$ & $\begin{array}{l}-0.502^{* \star *} \\
(-2.70)\end{array}$ & $\begin{array}{l}-0.447^{*} \\
(-2.28)\end{array}$ \\
\hline GRGDP & $\begin{array}{l}-0.011^{*} \\
(-2.07)\end{array}$ & $\begin{array}{l}-0.011^{* * *} \\
(-2.69)\end{array}$ & $\begin{array}{l}-0.009^{* *} \\
(-2.20)\end{array}$ & $\begin{array}{l}-0.007^{\star} \\
(-1.73)\end{array}$ & $\begin{array}{c}-0.0043 \\
(-0.84)\end{array}$ & $\begin{array}{l}-0.009^{* *} \\
(-2.00)\end{array}$ & $\begin{array}{l}-0.007 \\
(-1.58)\end{array}$ & $\begin{array}{c}-0.0064 \\
(-1.34)\end{array}$ \\
\hline LPOP & $\begin{array}{l}0.173^{*} \\
(1.68)\end{array}$ & $\begin{array}{l}0.137 \\
(1.36)\end{array}$ & $\begin{array}{l}0.136 \\
(1.48)\end{array}$ & $\begin{array}{l}1.118 \\
(1.33)\end{array}$ & $\begin{array}{l}1.154^{* *} \\
(2.22)\end{array}$ & $\begin{array}{l}1.762^{* *} \\
(2.81)\end{array}$ & $\begin{array}{l}1.540 * \\
(2.49)\end{array}$ & $\begin{array}{l}1.521^{* *} \\
(2.45)\end{array}$ \\
\hline PD1 & $\begin{array}{l}-0.279^{* *} \\
(-3.11)\end{array}$ & $\begin{array}{l}-0.187^{* *} \\
(-2.18)\end{array}$ & $\begin{array}{l}-0.234^{\star \star *} \\
(-2.78)\end{array}$ & $\begin{array}{l}-0.23^{\star \star *} \\
(2.77)\end{array}$ & $\begin{array}{l}-0.237 \\
(-0.95)\end{array}$ & $\begin{array}{l}0.044 \\
(0.19)\end{array}$ & $\begin{array}{l}-0.072 \\
(-0.32)\end{array}$ & $\begin{array}{l}-0.046 \\
(-0.19)\end{array}$ \\
\hline PD2 & $\begin{array}{l}0.074 \\
(0.98)\end{array}$ & $\begin{array}{l}0.115^{*} \\
(1.68)\end{array}$ & $\begin{array}{l}0.040 \\
(0.57)\end{array}$ & $\begin{array}{l}0.020 \\
(0.28)\end{array}$ & $\begin{array}{l}0.118 \\
(0.90)\end{array}$ & $\begin{array}{l}0.241^{* *} \\
(2.02)\end{array}$ & $\begin{array}{l}0.151 \\
(1.25)\end{array}$ & $\begin{array}{l}0.151 \\
(1.19)\end{array}$ \\
\hline HIPC & $\begin{array}{l}0.415^{* *} \\
(2.19)\end{array}$ & $\begin{array}{l}0.362^{* *} \\
(1.97)\end{array}$ & $\begin{array}{l}0.256 \\
(1.51)\end{array}$ & $\begin{array}{l}0.281 \\
(1.71)\end{array}$ & & & & \\
\hline $\mathrm{N}$ & 178 & 177 & 177 & 176 & 178 & 177 & 177 & 176 \\
\hline $\mathrm{R}^{2}$ & 0.24 & 0.30 & 0.40 & 0.43 & 0.0004 & 0.006 & 0.001 & 0.003 \\
\hline $\operatorname{Prob}(\text { chi2 })^{2)}$ & 0.39 & 0.16 & 0.56 & 0.37 & & & & \\
\hline
\end{tabular}

1) The dependent variable is log total external debt to GDP ratio (LEDTGDP).

2) The Hausman test is in favour of the random effects model.

3) The asterisks indicate significance levels at 10\%, $5 \%$ and $1 \%$ respectively.

4) The members in parentheses are $t$-values. 
Table 5

Differences in Covariates between HIPCs and Non-HIPCs (1982 - 1998)

\begin{tabular}{|l|c|c|c|c|c|c|c|c|c|}
\hline $\begin{array}{l}\text { Average } \\
\text { values }\end{array}$ & \multicolumn{3}{|c|}{$\begin{array}{c}\text { Heavily indebted poor } \\
\text { countries (HIPCs) }\end{array}$} & \multicolumn{3}{c|}{$\begin{array}{c}\text { Non-heavily indebted } \\
\text { countries (NON-HIPCS) }\end{array}$} & \multicolumn{3}{c|}{ Differences between the means } \\
\hline & $1982-1987$ & $1988-1993$ & $1994-1998$ & $1982-1987$ & $1988-1993$ & $1994-1998$ & $1982-1987$ & $1988-1993$ & $1994-1998$ \\
\hline LEDTG & 4.12 & 4.62 & 4.82 & 3.97 & 3.95 & 3.84 & 0.15 & 0.67 & 0.98 \\
\hline LPOP & 15.74 & 15.91 & 16.05 & 16.02 & 16.15 & 16.26 & -0.28 & -0.25 & -0.21 \\
\hline CFLX & -10.63 & 52.99 & 119.26 & -1.36 & 9.86 & 24.19 & -9.26 & 43.13 & 95.07 \\
\hline SDX & 53.25 & 27.88 & 46.88 & 1580.95 & 772.20 & 1641.75 & -1527.7 & -744.33 & -1594.8 \\
\hline MGDP & 32.67 & 30.12 & 38.92 & 37.20 & 35.84 & 39.38 & -4.54 & -5.72 & -0.46 \\
\hline LGDP & 22.34 & 22.75 & 22.92 & 23.64 & 24.15 & 24.49 & -1.30 & -1.40 & -1.58 \\
\hline GRGDP & 4.18 & 11.33 & 2.63 & 2.60 & 10.90 & 6.66 & 1.58 & 0.43 & -4.03 \\
\hline TDSX & 23.95 & 32.03 & 27.06 & 23.15 & 23.79 & 17.02 & 0.79 & 8.24 & 10.04 \\
\hline LTOTG & 2.70 & -4.50 & 1.60 & -3.72 & 0.61 & 0.39 & 6.42 & -5.11 & 1.21 \\
\hline
\end{tabular}

Table 6

The Impact of Each Variable on the Difference in the Log of Total External Debt to GDP Ratio between HIPCs and Non-HIPCs $(1982-1998)^{1)}$

\begin{tabular}{|l|c|c|c|c|c|c|}
\hline & \multicolumn{3}{|c|}{ Random effects model } & \multicolumn{3}{c|}{ Fixed effects model } \\
\cline { 2 - 7 } & $1982-1987$ & $1988-1993$ & $1994-1998$ & $1982-1987$ & $1988-1993$ & $1994-1998$ \\
\hline LPOP & 0.70 & 0.60 & 0.50 & 12.60 & 0.11 & 9.59 \\
\hline CFLX & 1.30 & 6.00 & 13.30 & 1.00 & 4.31 & 9.50 \\
\hline SDX & 6.10 & 3.00 & 6.40 & 15.20 & 7.41 & 15.94 \\
\hline MGDP & 1.80 & 2.20 & 0.20 & 1.00 & 1.00 & 0.07 \\
\hline LGDP & 27.70 & 29.90 & 33.70 & 58.00 & 62.31 & 70.48 \\
\hline GRGDP & 1.10 & 0.30 & 2.80 & 1.00 & 0.17 & 1.61 \\
\hline TDSX & 0.80 & 8.10 & 9.80 & 0.47 & 4.97 & 6.02 \\
\hline LTOTG & 1.50 & 1.20 & 0.30 & 1.00 & 1.00 & 0.24 \\
\hline
\end{tabular}

1). The effects of each variable on the difference in total external debt to GDP ratio between HIPCs and non-HIPCs was calculated as follows: First, I take the difference in each covariates between the two groups as shown in Table 5. Second, I take the regression coefficients of each covariate from column 4 and 8 of Table 6 for the random and fixed effects models, respectively. Finally I multiplied the coefficients by the differences. 
Table 7

Regression Results for HIPC Panel (Cross-section pooled-time series, 1982 - 1998)1)

\begin{tabular}{|c|c|c|c|c|}
\hline Variable & 1 & 2 & 3 & 4 \\
\hline CONST & $\begin{array}{l}2.025 \\
(0.82)\end{array}$ & $\begin{array}{l}2.891 \\
(1.21)\end{array}$ & $\begin{array}{l}3.381 \\
(1.45)\end{array}$ & $\begin{array}{l}3.879^{*} \\
(1.73)\end{array}$ \\
\hline SDX & $\begin{array}{c}-0.0007 \\
(-1.42)\end{array}$ & $\begin{array}{c}-0.0008^{*} \\
(-1.81)\end{array}$ & $\begin{array}{c}-0.0008^{*} \\
(-1.84)\end{array}$ & $\begin{array}{c}-0.0006 \\
(-1.46)\end{array}$ \\
\hline CFLX & & $\begin{array}{c}0.0013^{\star *} \\
(2.17)\end{array}$ & $\begin{array}{c}0.0013^{* *} \\
(2.25)\end{array}$ & $\begin{array}{c}0.0012 * \\
(2.31)\end{array}$ \\
\hline TDSX & & & $\begin{array}{c}0.0075^{*} \\
(1.96)\end{array}$ & $\begin{array}{l}0.082^{* *} \\
(2.27)\end{array}$ \\
\hline LTOTG & & & & $\begin{array}{c}-0.0086^{* * *} \\
(-2.83)\end{array}$ \\
\hline MDGDP & $\begin{array}{c}0.0285^{* * *} \\
(5.21)\end{array}$ & $\begin{array}{c}0.0244^{* * *} \\
(4.28)\end{array}$ & $\begin{array}{c}0.0244^{*+*} \\
(4.40)\end{array}$ & $\begin{array}{c}0.023^{t+*} \\
(4.51)\end{array}$ \\
\hline LGDP & $\begin{array}{l}0.046 \\
(0.29) \\
\end{array}$ & $\begin{array}{l}0.060 \\
(0.39) \\
\end{array}$ & $\begin{array}{c}0.0134 \\
(0.09)\end{array}$ & $\begin{array}{l}-0.016 \\
(-0.11) \\
\end{array}$ \\
\hline GRGDP & $\begin{array}{c}-0.022^{* *} \\
(-2.49)\end{array}$ & $\begin{array}{c}-0.020^{* *} \\
(-2.28)\end{array}$ & $\begin{array}{c}-0.0204^{* *} \\
(-2.39)\end{array}$ & $\begin{array}{c}-0.0214^{* * *} \\
(-2.67)\end{array}$ \\
\hline LPOP & $\begin{array}{l}0.054 \\
(0.34)\end{array}$ & $\begin{array}{c}-0.0198 \\
(-0.11)\end{array}$ & $\begin{array}{l}0.0033 \\
(0.20)\end{array}$ & $\begin{array}{l}0.022 \\
(0.14)\end{array}$ \\
\hline PD1 & $\begin{array}{c}-0.582^{* * *} \\
(-3.19)\end{array}$ & $\begin{array}{l}-0.402 \\
(-2.12)\end{array}$ & $\begin{array}{c}-0.413^{* *} \\
(-2.24)\end{array}$ & $\begin{array}{l}-0.423^{* *} \\
(-2.44)\end{array}$ \\
\hline PD2 & $\begin{array}{l}0.123 \\
(0.73)\end{array}$ & $\begin{array}{l}0.167 \\
(1.03)\end{array}$ & $\begin{array}{c}0.1234 \\
(0.77)\end{array}$ & $\begin{array}{l}0.048 \\
(0.32)\end{array}$ \\
\hline $\mathrm{N}$ & 62 & 61 & 61 & 61 \\
\hline $\mathrm{R}^{2}$ & 0.52 & 0.56 & 0.59 & 0.65 \\
\hline
\end{tabular}

1) The dependent variable is log of total external debt to GDP ratio (LEDTG).

Turning to the results of the regression, they indicate that, deflating the total debt stock by GDP in the framework of a panel data, the results for income per capita variable (LGDP) has a negative and statistically significant coefficient (see Table 4). This seems to suggest that, controlling the independent variables, country-specific and time-specific factors, it is low-income rather than high-income countries that have a greater desire to borrow overseas. This result is consistent with the gap models that the saving-investment gap (poverty) is one of the key determinants of the demand for overseas borrowing. From the results, it also implies that countries with lower growth of real GDP per capita (GDPG) tend to have higher demand for foreign resources than those with higher growth rates. In the framework of the fixed effects model, it seems that more populous countries (LPOP) have higher demand for external borrowing compared to countries with less population.

However, since the Hausman test is in favour of the random effects model, the results should be interpreted with caution. Moreover, from the results, it implies that countries that are open to international trade (MGDP) have a greater tendency to 
borrow overseas as opposed to countries that are relatively closed. Income instability (SDX) seems to be another key player in condemming countries to external indebtedness. The external environment has indeed enormously contributed to aggravating poor countries external balance situation. From the regression results, it implies that higher past total debt service payments (TDSX) provoke further demand for external borrowing by developing countries. In addition, from the regression results, it appears that countries with high capital flight (CFLX) have also higher demand for external borrowing. Finally, despite the theoretical argument that the worsening of the terms of trade leads to higher demand for external financing, the results suggest the opposite, the result that must be interpreted as anomalous. However, it might also be due to credit ceiling by creditor governments.

A separate cross-section pooled time-series regressions for HIPCs that are in Table 6 indicate that SDX is negatively related to the demand for external debt. This suggests that countries with higher income instability tend to demand less borrowing overseas, a result that must be interpreted rather as anomalous. On the other hand, such a result may also be the outcome of a credit ceiling from the part of creditors. This may be, for example, because countries with unsustainable export revenues do have less incentives to pay back their past debt or simply do no posses enough collateral and this may worsen their access to the borrowing market. Capital flight seems to have contributed to HIPCs external indebtedness. The total debt service payment and the loss in the terms of trade have also stimulated further external borrowing. HIPCs that are relatively open - higher share of imports to GDP (MGDP) borrowed more than their less-open HIPCs counterparts do. In addition, more open HIPCs have a tendency to payback their past debt since the penalty (trade embargo, for instance) of default is higher for these countries. The LGDP indicates that relatively richer HIPCs had higher demand for external debt and this has been almost one to one. This also indicates that relatively higher-income HIPCs had a tendency to payback their debt, as they want to borrow in the future. The other variables have not been significant.

\section{Conclusion and the Policy Implication}

This paper was aimed at empirically addressing a question of enormous significance for the external balance situation and economic development of developing nations in the past two decades. The main task was empirically exploring the factors that lead countries to the overseas borrowing markets that affect international relations.

To answer this question, several empirical strategies have been employed. The first attempt was to check the robustness of previous other empirical results in this area. The most relevant and recent in this case was that of Easterly (2002), who empirically addresses HIPCs external indebtedness. It appears that though in general his studies are robust, the implementation of a cross-section pooled time series approach rather than a simple cross-section one generates a more robust empirical results as it enables one to incorporate time-specific factors that allow to control changes in the global macroeconomic-policy environment, which affect the development of external indebtedness over time.

Moving to a broader approach of empirically investigating the causes of external indebtedness, again using both random and fixed effects models and cross-section pooled time series, the results suggest that capital flight, debt service payments, the imports to GDP ratio, income per capita, and the growth rate of GDP are the key determinants of the demand for overseas borrowing. A separate cross-section pooled times series analysis for HIPCs indicates that this group's demand for overseas 
borrowing was driven mainly by sluggish economic growth, high past debt service payments, income instability, and demand for foreign exchange to finance their import bills (this makes sense, as most of them are holding currencies that are not freely convertible), which is partly the reflection of the foreign-exchange gap.

The policy implications of this study are relatively straightforward. First, the fact that external factors are one of the causes of the external indebtedness of developing countries may imply that developed nations should bear part of the responsibility, as they are part of the problem. Second, the empirical evidence here and other studies may seem to suggest that poverty and past-accumulated debt are the cardinal factors responsible for the failure of poor nations in meeting their contractual international debt obligations. This may seem to support the call for debt relief for poor nations, as further supply of loans to these nations would simply lead them to a notoriously known problem of "circular financing", hence, taking more expensive new loans to pay back cheaper old ones, leaving the circle unbroken, and poor nations stay poor forever. In this context, the new HIPCs' initiative introduced by the IMF and the World Bank should be recognized as a plausible start towards a real solution to the debt crisis of poor nations. Finally, developing nations should have a sound debt management strategy, as foreign loans, beyond certain limits, are harmful rather than helpful towards achieving sustainable economic growth.

\section{References}

Agenor, P. R., Montiel, P. J. (1999), Development Macroeconomics. Princeton: Princeton University Press.

Bacha, E. L. (1990), "A Three-gap Model of Foreign Transfers and the GDP Growth Rate in Developing Countries." Journal of Development Economics, 32(2), pp. 279-296.

Basu, K. B. (2000), Analytical Development Economics: The Less Developed Economy Revised. Cambridge, MA: MIT Press.

Chacholiades, M. (1990), International Economics. New York: McGraw Hill.

Claessens, S., Detragiache, E., Wickham, P., Kanbur, R. (1996), "Analytical Aspects of the Debt Problems of Heavily Indebted Poor Countries." Washington, The World Bank, Policy Research Working Paper 1618.

Dijkstra, G., Niels, H. (2001), "The Uncertainty of Debt Service Payments and Economic Growth of Highly Indebted Poor Countries: Is There a Case for Debt Relief?" Helsinki, WIDER Discussion Paper No. 122.

Dornbusch, R. (1984), "External Debt, Budget Deficits, and Disequilibrium Exchange Rates", in Smith, G. W., Cuddington, J. T. (1985), "International Debt and the Developing Countries." Washington, A World Bank Symposium, pp. 213-235.

Dymski, G. A. (2001), "The International Debt Crisis" (http/www.wider.unu.conference/conference2001).

Easterly, W. (2002), "How Did Heavily Indebted Poor Countries Become Heavily Indebted? Reviewing Two Decades of Debt Relief". World Development, 30(10), pp. 1677-1696. (1999), "The Ghost of Financing Gap: Testing the Growth Model Used in the International Financial Institutions." Journal of Development Economics, 60(2), pp. 423-438.

Eichengreen, B. J., Portes, R. (1986), "Debt and Default in the 1930s: Causes and Consequences." European Economic Review, 30(3), pp. 599-640.

Eaton, J., Gersowitz, M. (1981), "Debt with Potential Repudiation: Theoretical and Empirical Analysis." Review of Economic Studies, 48(2), pp. 289-309.

Ferraro, V., Rosser, M. (1994), "Global Debt and Third World Development", in Klare, M., Thomas, D., eds., World Survey: Challenges for a New Century. New York: St. Martin's Press, pp. 332-355.

Hajivassiliou, V. A. (1987), "The External Debt Repayments Problem of LDC's: An Econometric Model Based on Panel Data." Journal of Econometrics, 36(1-2), pp. 205-230.

IMF (2003), "Debt Sustainability in Low-income Countries - Towards a Forward-looking Strategy." Washington, IMF, Policy Development and Review Department. 
Kaminsky, G. L., Pereira, A. (1996), "The Debt Crisis: Lessons of the 1980s for the 1990s.” Journal of Development Economics, 50(1), pp. 1-24.

McFadden, D. et al. (1983), "Is There Life after Debt? An Econometric Analysis of the Creditworthiness of Developing Countries", in Smith, G. W., Cuddington, J. T., "International Debt and the Developing Countries." Washington, A World Bank Symposium, pp. 179-209.

Nafziger, E. W. (1993), The Debt Crisis in Africa. Baltimore: John Hopkins University Press.

Nigel, H. M. (1995), "The International Debt Crisis", in Ghatak, S., ed., Introduction to Development Economics. London: TJ Press, pp. 424-448.

Pilbeam, K. (1992), International Finance. London: Macmillan.

Root, F. (1990), International Trade and Investment. Cincinnati: South-Western Publishing Co.

Sachs, J., Berg, A. (1988), "The Debt Crisis: Structural Explanations of Country Performance." Cambridge, MA, NBER Working Series, No. 2607.

Serieux, J. E. (2001), "Debt of the Poorest Countries: Anatomy of a Crisis Kept on Hold." Canadian Journal of Development Studies, 22(2), pp. 305-342.

Schwartz, A. J. (1988), "International Debts: What's Fact and What's Fiction." Economic Inquiry, 27(1), pp. 1-19.

Taylor, L. (1994), “Gap Models.” Journal of Development Economics, 45(1), pp. 17-34.

WB (2000), "Global Development Finance, CD-ROM." Washington, DC, The World Bank. (2000), "World Development Indicators, CD-ROM." Washington, DC, The World Bank.

Workie Tiruneh, M. (2002), "Exogenous Causes of the Debt Crisis and the Subsequent Divergence of Developing Countries: Could They Be Legitimate Arguments for Debt Relief?" International Issues, 11(3), pp. 48-73 (Slovak Institute for International Studies, Bratislava). 